Atmos. Chem. Phys., 13, 9971-9974, 2013

www.atmos-chem-phys.net/13/9971/2013/

doi:10.5194/acp-13-9971-2013

(c) Author(s) 2013. CC Attribution 3.0 License.

\title{
Technical Note: Estimating aerosol effects on cloud radiative forcing
}

\author{
S. J. Ghan \\ Pacific Northwest National Laboratory, Richland, Washington, USA \\ Correspondence to: S. J. Ghan (steve.ghan@pnnl.gov)
}

Received: 11 June 2013 - Published in Atmos. Chem. Phys. Discuss.: 12 July 2013

Revised: 9 September 2013 - Accepted: 14 September 2013 - Published: 9 October 2013

\begin{abstract}
Estimating anthropogenic aerosol effects on the planetary energy balance through the aerosol influence on clouds using the difference in cloud radiative forcing from simulations with and without anthropogenic emissions produces estimates that are positively biased. A more representative method is suggested using the difference in cloud radiative forcing calculated as a diagnostic with aerosol scattering and absorption neglected. The method also yields an aerosol radiative forcing decomposition that includes a term quantifying the impact of changes in surface albedo. The method requires only two additional diagnostic calculations: the whole-sky and clear-sky top-of-atmosphere radiative flux with aerosol scattering and absorption neglected.
\end{abstract}

\section{Introduction}

The Intergovernmental Panel on Climate Change Fifth Assessment Report recommends that anthropogenic aerosol effects on the planetary energy balance be expressed as an effective radiative forcing (ERF) that allows clouds to respond to the aerosol while surface temperature is prescribed. One recommended way to calculate the ERF is using the radiative flux perturbation (RFP) method from the top-of-atmosphere energy balance difference between simulations with and without anthropogenic emissions but the same ocean surface conditions (Hanson et al., 2005; Haywood et al., 2009; Lohmann et al., 2010). Lohmann et al. (2010) showed that the RFP estimate of aerosol radiative forcing agrees well with estimates using diagnostic radiation calls with presentday and preindustrial aerosol and the same meteorology. This suggests the RFP method can be used to estimate aerosol effects involving all of the "fast physics" of climate, including precipitation.
Distinguishing contributions to aerosol radiative forcing from scattering and absorption of sunlight by aerosols and from aerosol-induced changes in clouds has historically been essential for understanding the mechanisms involved and the dependence of aerosol radiative forcing estimates on the representation of the associated processes. The literature on estimates of aerosol radiative forcing is filled with estimates that distinguish such contributions (Forster et al., 2007; Bond et al., 2013).

Estimates of anthropogenic aerosol effects through the aerosol influence on clouds are often approximated (Rotstayn and Liu, 2005; Hoose et al., 2009; Chen et al., 2010; Gettelman et al., 2012) by the change in the cloud radiative forcing when anthropogenic emissions are introduced in simulations: $\Delta C$, where $\Delta$ is the difference between atmosphere simulations with and without anthropogenic emissions but the same ocean conditions (Rotstayn and Penner, 2001; Haywood et al., 2009) and natural emissions, and $C=F-F_{\text {clear }}$ is the cloud radiative forcing, with $F$ the shortwave radiative flux at the top of the atmosphere and $F_{\text {clear }}$ the flux calculated as a diagnostic with clouds neglected.

While such an estimate is easy to calculate, I show here that $\Delta C$ is a significantly biased estimate of anthropogenic aerosol effects on cloud radiative forcing (the sum of aerosol indirect effects and semi-direct effects). Since the total aerosol forcing from the RFP method is simply $\Delta F$, using $\Delta C$ to estimate anthropogenic aerosol effects on cloud radiative forcing implies the direct anthropogenic radiative forcing from scattering and absorption by anthropogenic aerosol, which (neglecting contributions from aerosol effects on surface albedo) equals the difference between the total forcing and the change in cloud forcing, is equivalent to $\Delta F_{\text {clear }}$. This estimate of direct radiative forcing is biased because it neglects radiative warming enhancement by absorbing aerosol above clouds and because it exaggerates radiative cooling by 

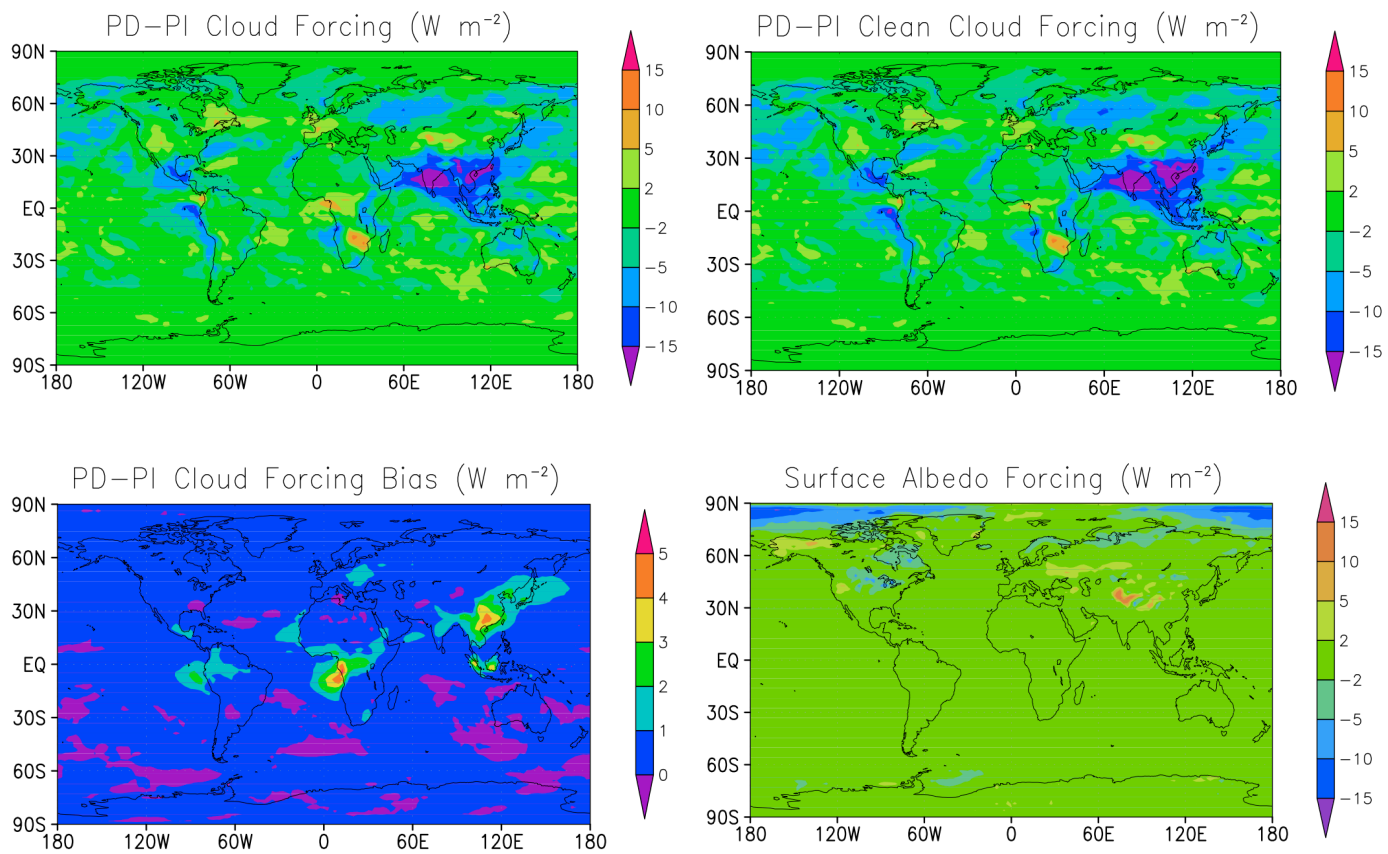

Fig. 1. Present-day - preindustrial difference in five-year annual mean top-of-atmosphere shortwave cloud radiative forcing (top left), cleansky shortwave cloud radiative forcing (top right), the difference (bottom left) and the surface albedo forcing (bottom right) simulated by CAM5.1.

scattering aerosol above clouds. If the direct forcing estimate is biased, then that implies the estimate of aerosol effects on cloud radiative forcing is also biased.

\section{A more representative method}

A more realistic estimate of direct forcing is $\Delta\left(F-F_{\text {clean }}\right)$ (Lohmann et al., 2010; Ghan et al., 2012; hereafter G12), where $\Delta$ is defined as above and $F_{\text {clean }}$ is the radiative flux calculated as an additional diagnostic from the same simulations, but neglecting the scattering and absorption of solar radiation by all of the aerosol. Similarly, a more realistic estimate of aerosol effects on cloud radiative forcing is $\Delta\left(F_{\text {clean }}-F_{\text {clear,clean }}\right)=\Delta C_{\text {clean }}$, where $F_{\text {clear,clean }}$ is the flux calculated as an additional diagnostic, but neglecting scattering and absorption by both clouds and aerosols. The total aerosol forcing then becomes $\Delta F=\Delta\left(F-F_{\text {clean }}\right)+$ $\Delta C_{\text {clean }}+\Delta F_{\text {clear,clean. }}$ The last term is largely the contribution of changes in surface albedo induced by the aerosol. As we shall see, it is small but not negligible, particularly in some regions.

Figure 1 shows the spatial distributions of the annual mean $\Delta C, \Delta C_{\text {clean }}$, and the difference $\left(\Delta C-\Delta C_{\text {clean }}\right)$ from present-day and preindustrial simulations by Version 5.1 of the Community Atmosphere Model, CAM5.1 (G12). The $\Delta C$ and $\Delta C_{\text {clean }}$ distributions look quite similar. However, the bias $\Delta C-\Delta C_{\text {clean }}$ is positive almost everywhere, with a global mean of $0.42 \mathrm{~W} \mathrm{~m}^{-2}$, which is $22 \%$ of the global mean of $\Delta C_{\text {clean }}=-1.92 \mathrm{~W} \mathrm{~m}^{-2}$. The bias is particularly large off the coast of Angola, where absorbing aerosol above cloud is known to produce positive direct forcing (Chand et al., 2009), and over south China, where direct forcing is also estimated by CAM5.1 to be positive (G12). The positive bias can be explained by the tendency of absorbing aerosol to make shortwave cloud forcing more positive by increasing radiative warming when the absorbing aerosol lies above cloud (such as off the coast of Angola), and by the tendency of scattering aerosol to make shortwave cloud forcing more positive by enhancing radiative cooling more over clear sky and dark surfaces than when clouds are present. Since these two mechanisms add rather than cancel, this positive bias is likely to be robust, i.e., common to other models, particularly those including absorbing anthropogenic aerosol.

The annual mean surface albedo term, also shown in Fig. 1, ranges regionally between -10 and $+10 \mathrm{~W} \mathrm{~m}^{-2}$, and is $-0.07 \mathrm{~W} \mathrm{~m}^{-2}$ in the global mean. This term includes effects of both changes in snow albedo due to deposition of absorbing aerosol, and changes in snow cover induced by deposition and by the other aerosol forcing mechanisms. The positive forcing in Alaska, eastern Europe and especially Tibet is a signature of snow albedo reduction due to deposition of black carbon on snow. Since the forcing is negative in the Arctic, where one expects snow albedo changes to produce a radiative warming, the warming due to reduction in snow albedo in the Arctic is apparently dominated by radiative cooling due to increases in snow cover. This interpretation is 
confirmed by simulated increases in snowfall and snow water over the Arctic (not shown).

Although one might expect the expression for the surface albedo term to overestimate the magnitude of the impact of surface albedo changes on the planetary energy balance because it neglects the attenuation of the surface signal by clouds, for CAM5.1 the surface albedo term actually dominates the other aerosol forcing terms in the Arctic and hence drives the total aerosol radiative forcing there. Since the simulated direct forcing and cloud forcing by anthropogenic aerosol are small in the Arctic, the enhanced snowfall there must be driven by either radiative forcing from elsewhere or by aerosol-induced reduction in precipitation efficiency from warm clouds, leading to more transport of water to the Arctic. This surprising result might not be produced by other climate models, but it certainly suggests care is needed in attributing aerosol radiative forcing to direct and cloud effects.

In principle, the same approach should also be applied to longwave radiation. However, the small size of most anthropogenic aerosol particles suggests that the difference between $\Delta C$ and $\Delta C_{\text {clean }}$ is small for longwave radiation. Indeed, we find that for CAM5 the difference is locally less than $0.2 \mathrm{~W} \mathrm{~m}^{-2}$ (in regions where dust changes) and globally less than $0.01 \mathrm{~W} \mathrm{~m}^{-2}$. Note that there is a difference between the common clear sky estimate of longwave cloud forcing using the grid cell mean humidity and an estimate using the humidity for the clear sky fraction of the grid cell, estimated by Sohn et al. (2010) to be about $10 \%$.

\section{Recommendation}

In summary, while I do not recommend any changes in how the total aerosol radiative forcing is estimated, for future estimates of aerosol radiative forcing I recommend use of the following decomposition:

Direct radiative forcing: $\Delta\left(F-F_{\text {clean }}\right)$

Cloud radiative forcing: $\Delta\left(F_{\text {clean }}-F_{\text {clear, clean }}\right)=\Delta C_{\text {clean }}$

Surface albedo forcing: $\Delta F_{\text {clear,clean }}$

All simulations performed to quantify aerosol radiative forcing should save $F, F_{\text {clean }}$, and $F_{\text {clear,clean }}$ in the simulation history. All climate models already have the ability to calculate $F_{\text {clear }}$ as a diagnostic for estimating cloud radiative forcing, so these additional diagnostics should not introduce an excessive burden. None of these diagnostics affect the estimate of the total aerosol radiative forcing $\Delta F$ or any aspects of the climate simulations, but provide estimates of the different forcing mechanisms that are more consistent with the processes involved. Further decomposition of the aerosol effect on cloud radiative forcing into contributions from indirect effects and semi-direct effects would require another pair of simulations in which aerosol absorption is neglected (G12).
Acknowledgements. Phil Rasch prodded me to think more deeply about decomposition, and Xiaohong Liu ran the simulations and provided the model history. This work was funded by the US Department of Energy, Office of Science, Scientific Discovery through Advanced Computing (SciDAC) Program and by the Office of Science Earth System Modeling Program. The CESM project is supported by the National Science Foundation and the Office of Science (BER) of the US Department of Energy. Computing resources were provided by the Climate Simulation Laboratory at NCAR's Computational and Information Systems Laboratory (CISL), sponsored by the National Science Foundation and other agencies. The Pacific Northwest National Laboratory is operated for DOE by Battelle Memorial Institute under Contract DE-AC06-76RLO 1830.

Edited by: K. Tsigaridis

\section{References}

Bond, T., Doherty, S. J., Fahey, D. W., Forster, P. M., Berntsen, T., Boucher, O., DeAngelo, B., Flanner, M. G., Ghan, S., Kärcher, B., Koch, D., Kinne, S., Kondo, Y., Quinn, P. K., Sarofim, M. C., Schultz, M. G., Schulz, M., Venkataraman, C., Zhang, H., Zhang, S., Bellouin, N., Guttikunda, S., Hopke, P. K., Jacobson, M. Z., Kaiser, J. W., Klimont, Z., Lohmann, U., Schwarz, J. P., Shindell, D., Storelvmo, T., Warren, S. G., and Zender, C.: Bounding the role of black carbon aerosol in the climate system: A scientific assessment, J. Geophys. Res., 118, 1-173, doi:10.1002/jgrd.50171, 2013.

Chand, D., Wood, R., Anderson, T. L., Satheesh, S. K., and Charlson, R. J.: Satellite-derived direct radiative effect of aerosols dependent on cloud cover, Nat. Geosci., 2, 181-184, doi:10.1038/Ngeo437, 2009.

Chen, W. T., Lee, Y. H., Adams, P. J., Nenes, A., and Seinfeld, J. H.: Will black carbon mitigation dampen aerosol indirect forcing?, Geophys. Res. Lett., 37, L09801, doi:10.1029/2010g1042886, 2010.

Forster, P., Ramaswamy, V., Artaxo, P., Berntsen, T., Betta, R., Fahey, D. W., Haywood, J., Lean, J., Lowe, D. C., Myhre, G., Nganga, J., Prinn, R., Raga, G., Schulz, M., and Van Dorland, R.: Changes in atmospheric constituents and in radiative forcing, in Climate Change 2007: The Physical Science Basis. Contribution of Working Group I to the Fourth Assessment Report of the Intergovernmental Panel on Climate Change, edited by: Solomon, S., Qin, D., Manning, M., Chen, Z., Marquis, M., Averyt, K. B., Tignor, M., and Miller, H. L., Cambridge University Press, New York, NY, 2007.

Gettelman, A., Liu, X., Barahona, D., Lohmann, U., and Chen, C.: Climate impacts of ice nucleation, J. Geophys. Res., 117, D20201, doi:10.1029/2012JD017950, 2012.

Ghan, S. J., Liu, X., Easter, R. C., Zaveri, R., Rasch, P. J., Yoon, J. H., and Eaton, B.: Toward a minimal representation of aerosols in climate models: Comparative decomposition of aerosol direct, semidirect, and indirect radiative forcing, J. Climate, 25, 64616476, 2012.

Hansen, J., Sato, M., Ruedy, R., Nazarenko, L., Lacis, A., Schmidt, G. A., Russell, G., Aleinov, I., Bauer, M., Bauer, S., Bell, N., Cairns, B., Canuto, V., Chandler, M., Cheng, Y., Del Genio, A., Faluvegi, G., Fleming, E., Friend, A., Hall, T., Jackman, C., Kelley, M., Kiang, N., Koch, D., Lean, J., Lerner, J., Lo, K., Menon, 
S., Miller, R., Minnis, P., Novakov, T., Oinas, V., Perlwitz, J., Rind, D., Romanou, A., Shindell, D., Stone, P., Sun, S., Tausnev, N., Thresher, D., Wielicki, B., Wong, T., Yao, M., and Zhang, S.: Efficacy of climate forcings, J. Geophys. Res., 110, D18104, doi:18110.11029/12005jd005776, 2005.

Haywood, J. M., Donner, L. J., Jones, A., and Golaz, J.-C.: Global indirect radiative forcing caused by aerosols: IPCC (2007) and beyond, in: Clouds in the Perturbed Climate System, edited by: Heintzenberg, J. and Charlson, R. J., MIT Press, Cambridge, 451-467, 2009.

Hoose, C., Kristjánsson, J. E., Iversen, T., Kirkevåg, A., Seland, Ø., and Gettelman, A.: Constraining cloud droplet number concentration in GCMs suppresses the aerosol indirect effect, Geophys. Res. Lett., 36, L12807, doi:10.1029/2009GL038568, 2009.

Lohmann, U., Rotstayn, L., Storelvmo, T., Jones, A., Menon, S., Quaas, J., Ekman, A. M. L., Koch, D., and Ruedy, R.: Total aerosol effect: radiative forcing or radiative flux perturbation?, Atmos. Chem. Phys., 10, 3235-3246, doi:10.5194/acp-10-32352010, 2010.
Rotstayn, L. D. and Liu, Y.: A smaller global estimate of the second indirect aerosol effect, Geophys. Res. Lett., 32, L05708, doi:10.1029/2004GL021922, 2005.

Rotstayn, L. D. and Penner, J. E.: Indirect aerosol forcing, quasi forcing, and climate response, J. Climate, 14, 2960-2975, 2001.

Sohn, B. J., Nakajima, T., Satoh, M., and Jang, H.-S.: Impact of different definitions of clear-sky flux on the determination of longwave cloud radiative forcing: NICAM simulation results, Atmos. Chem. Phys., 10, 11641-11646, doi:10.5194/acp-1011641-2010, 2010. 